\title{
Economic Impact of GM Hysteria on EU Feed Market
}

\author{
József Popp ${ }^{1}$, Károly Petö ${ }^{2}$, Róbert Magda $^{3}$, Zoltán Lakner ${ }^{4}$ \\ ${ }^{1}$ Department of Economic Policy, University of Debrecen, Debrecen, Hungary; ${ }^{2}$ Department of Rural Development, University of \\ Debrecen, Debrecen, Hungary; ${ }^{3}$ Department of Economics, Károly Róbert College, Gyöngyös, Hungary; ${ }^{4}$ Department of Food Eco- \\ nomics, Budapest Corvinus University, Budapest, Hungary. \\ Email: poppj@agr.unideb.hu
}

Received May $19^{\text {th }}, 2013$; revised June $20^{\text {th }}, 2013$; accepted July $5^{\text {th }}, 2013$

Copyright (C) 2013 József Popp et al. This is an open access article distributed under the Creative Commons Attribution License, which permits unrestricted use, distribution, and reproduction in any medium, provided the original work is properly cited.

\begin{abstract}
A growing world population coupled with changing diet is projected to increase demand for food production by $70 \%$ by 2050. Helping farmers lose less of their crops will be a key factor in promoting food security. In addition to pesticides GM crops will continue to be a vital tool in the diverse range of technologies that can maintain and improve living standards for the people of the world. The EU is dependent for $65 \%$ on imports of protein-rich feedstuffs for which there are no substitutes in the short term. The EU livestock sector uses imported soybean, soybean meal and maize by-products as animal feed. Without an adequate supply of these feed ingredients, the EU's livestock production will loose competitiveness. However, demands from the EU differ to those from third countries with respect to the GM varieties grown, and what are authorised for import into the EU. The risk that supplies of soya products and maize by-products could be affected by the low-level presence of non-EU approved GM material has not been fully resolved as the EU has allowed just a $0.1 \%$ tolerance for this plus $0.05 \%$ tolerance for measuring uncertainty. This could cause supply problems for the animal feed industry, and ultimately supply of food to consumers. The importance of the EU market and EU requirements for the major soybean and maize exporter countries is declining over time and it is becoming increasingly difficult and costly to maintain a non-GM supply chain in the EU. Food companies and supermarkets will struggle to stay GM-free. EU member states dependent on imports will be forced to deal with more GM presence in their chain. Market forces are forcing governments to authorize products more efficiently, develop tolerance policies or tolerate unapproved varieties in their imports.
\end{abstract}

Keywords: GM Crops; GM Policy; GM Debate in the EU; Feed Market; Replacing Soybean with Pulses

\section{Introduction}

From 1960 to present the human population has more than doubled to reach seven billion people. The 7 billion world population is projected to increase by $30 \%$ to 9.2 billion by 2050. This increased population density, coupled with changes in dietary habits in developing countries towards high quality food (e.g. greater consumption of meat and milk products) and the increasing use of grains for livestock feed, is projected to increase demand for food production by $70 \%$ by 2050 , compared with average 2005-07 levels. At the same time the increase in arable land between 2005 and 2050 will be just $5 \%$ [1].

Globally, an average of $35 \%$ of potential crop yield is lost to pre-harvest pests [2]. In addition to the pre-harvest losses transport, pre-processing, storage, processing, packaging, marketing and plate waste losses are relatively high. Roughly one-third of the edible parts of food pro- duced for human consumption get lost or wasted globally. Food losses in industrialized countries are as high as in developing countries, but in developing countries more than $40 \%$ of the food losses occur at post harvest and processing levels, while in industrialized countries, more than $40 \%$ of the food losses occur at retail and consumer levels [3]. We can save also water and energy by reducing losses in the food chain.

A growing world population and a changing diet have led to continuously expanding areas of agricultural land, despite parallel increases in yields from existing cropland. Crop yields would continue to grow but at a slower rate than in the past. Yield growth will play an important role as only a slow expansion of agricultural land is expected. Helping farmers lose less of their crops will be a key factor in promoting food security. The beneficial outcome from use of genetically modified (GM) crops in addition to pesticides provides evidence that GM crops 
and pesticides will continue to be a vital tool in the diverse range of technologies that can maintain and improve living standards for the people of the world [4].

However, acceptance of GM crops is very heterogeneous. Public opinion in Europe is mostly seen to be critical (whether because of a lack of perceived personal benefits, ideologically motivated judgements, emotional responses or diffuse mistrust of governments and the media), while most people in the rest of the world are rather indifferent or (if they are farmers) increasingly in favour of GM crops. Differences also exist regarding both the number of GM crops authorised in different countries and the timing of their authorisation. The major GM crops - soybeans, maize, cotton and rapeseed-are also those crops that are the most heavily traded internationally, providing vital export revenues for many countries and industries but also providing a crucial supply of cheap feed and fibres for many importing countries, including the member states of the European Union (EU).

For climatic and agronomic reasons, the EU is unable to produce most of the oilseed meal and other proteinrich feedstuffs required to feed its livestock. Protein-rich soybean meal, as well as Corn Gluten Feed (CGF) and Distillers Dried Grain with Solubles (DDGS) are needed by livestock producers in the EU to achieve a balanced diet for their animals, especially as far as protein is concerned. There is no prospect for developing large scale domestic production of protein rich plants. Even with the increased land use of oilseeds for biofuels and stepping up production of protein crops such as field peas, field beans and sweet lupins to provide alternatives to soybean, at most they could only replace between $10 \%-20 \%$ of EU imports of soybeans and soybean meal. Without an adequate supply of these feed ingredients, the EU's livestock production will lose competitiveness and European livestock producers will lose market share. All EU imports of meat are produced from animals which may legally be fed with GM plants not yet authorised in the EU $[5,6]$.

But what is the situation like today? How important is the soybean meal use in the EU? Do pulses have the potential to replace soybean and soybean meal imports? Would this substitution have a significant impact on the global growth in soybean production? And what would be the consequences of an increase in peas or soybeans production for the production and the export potential of grain and oilseeds in the EU? What is the greatest challenge facing the feed market in the EU?

\section{Materials and Methods}

This study focuses mainly on EU GMO policy in the context of its economic impact on EU market. Data published in various international journals were used in the analysis. The database of FAO, USDA, European Commission, European Parliament and Toepfer International has also been used in the examination.

The literature addressing EU GM policies is already substantial. Several reports have addressed the effects of GM crops on the environment and on human health. However, the effects of agricultural biotechnology at the farm level - that is, from the point of view of the farmer - have received much less attention. And there is a lack of publications on farm-level GM crop benefits in Europe with the exception of Spain due to the small adoption rates of GM maize in Europe. The use of individual studies is furthermore hampered by the fact that these studies might use totally different methodologies (and motivations) to assess the economic effects of GM crops.

However, the import of soybean and soybean meal for EU livestock production has become the subject of an intensive political discussion. In 2002 already, the EU parliament ordered a special report on this subject and the most important result at that time was that the pulses production in the EU is not competitive to grain and oilseeds production [7]. Other studies highlighted that in the EU there is no prospect for developing large scale domestic production of protein rich plants, at most they could only replace between $10 \%-20 \%$ of EU imports of soybeans and soybean meal. Without an adequate supply of these feed ingredients, the EU's livestock production will loose competitiveness $[5,6]$. But what is the situation today? What about increasing the production of pulses in the EU? Is there a strategy for replacing soybean and soybean meal imports? This is the greatest challenge the feed market is facing today in the EU? This paper covers the analysis of all these questions as well.

The main objective of the present study is to characterize the dependence of the EU on imports of soybean and soybean meal for which there are no substitutes in the short term. As soybean meal can to a very small extent be substituted by other protein feedstuffs there is no strategy for replacing soya imports, however, global market realities are forcing change in Europe.

\section{Results and Discussion}

\subsection{Global Status of Commercialised GM Crops in 2012}

The global area planted to GM crops in 1996 was approximately 1.7 million hectares. GM crop production has increased each year since then, with an estimated 170 million hectares of GM crops in 28 countries planted in 2012 which represented $10 \%-11 \%$ of global cropland. The United States is the leading producer of GM crops accounting for 70 million hectares of the total GM crop area. Brazil is second, producing GM crops on 37 million hectares. Argentina is third with 24 million hectares of 
GMO area, followed by Canada, India, China, Paraguay and South Africa (Table 1).

Almost all of the global biotech crop area consists of soybeans, maize, cotton and canola. In 2012, GM soybeans accounted for the largest share $(48 \%)$, followed by maize $(33 \%)$, cotton $(14 \%)$ and canola $(5 \%)$. In terms of the share of total global plantings to these four crops, biotech traits accounted for $81 \%$ for soybean and cotton respectively, followed by maize $(35 \%)$ and canola $(30 \%)$ (Figure 1).

The percent adoption rate of GM maize was $90 \%$ in the USA, $65 \%$ in Argentina and the USA and 50\% for the summer maize and $65 \%$ for the winter maize in Brazil. The adoption rate of GM soybean reached $90 \%$ 99\% in the USA, Argentina and Brazil. Percent adoption rate of canola increased to $98 \%$ in Canada (Table 2).

Table 1. Area of GM crops by country in 2012 [8].

\begin{tabular}{|c|c|c|}
\hline Country & Area (M ha) & GM crops \\
\hline USA & 69.5 & $\begin{array}{l}\text { Soybean, maize, cotton, canola, } \\
\text { squash,, papaya, alfalfa, sugarbeet }\end{array}$ \\
\hline Brazil & 36.6 & Soybean, maize, cotton \\
\hline Argentina & 23.9 & Soybean, maize, cotton \\
\hline Canada & 11.6 & Canola, maize, soybean, sugarbeet \\
\hline India & 10.8 & Cotton \\
\hline China & 4.0 & $\begin{array}{l}\text { Cotton, tomato, poplar, papaya, } \\
\text { sweet pepper }\end{array}$ \\
\hline Paraguay & 3.4 & Soybean, maize, cotton \\
\hline South Africa & 2.9 & Soybean, maize, cotton \\
\hline
\end{tabular}

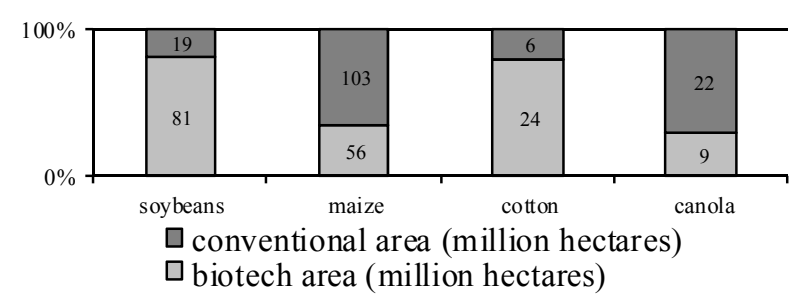

Figure 1. Share of GM crops in global plantings of key crops in 2012 [8].

Table 2. Adoption rate of GM crops in the leading exporting countries in 2012 [8].

\begin{tabular}{ccc}
\hline GM crops & Country & Adoption rate (\%) \\
\hline \multirow{3}{*}{ Soybean } & USA & 93 \\
& Argentina & 99 \\
\multirow{3}{*}{ Canola } & Brazil & 89 \\
& Canada & 98 \\
\multirow{2}{*}{ Maize } & USA & 90 \\
& Argentina & 65 \\
& Brazil* & $50-65$ \\
\hline
\end{tabular}

In 2012, of the 27 countries in the European Union, five-Spain, Portugal, Czech Republic, Slovakia and Romania - planted a record on 129 thousand hectares of Bt maize. Spain with a record adoption rate of $30 \%$ was by far the largest adopter planting $90 \%$ of the total $\mathrm{Bt}$ maize hectarage in the EU. The planned approval in 2014, subject to clearance of a new biotech potato named "Fortuna" resistant to late blight is potentially an important product that can meet EU policy and environmental needs to make potato production more sustainable by reducing heavy fungicide applications and decreasing production losses estimated at up to USD 1.5 billion annually in the EU alone, and USD 7.5 billon worldwide [8].

Biotech crops are accepted for import for food and feed use and for release in to the environment in 59 countries, including major food importing and exporting countries. The major GM crops-soybeans, maize, cotton and rapeseed - are also those crops that are the most heavily traded internationally, providing vital export revenues for many countries and industries but also providing a crucial supply of cheap feed and fibres for many importing countries.

\subsection{Effects on the Feedstuff Market in the EU}

The EU used to import significant quantities of maize byproducts from the USA for use as animal protein feed (CGF and DDGS). However, this trade declined sharply from 2007 because the USA adopted new GM maize crops before they were cleared for EU import. This was the first example of an asynchronous GM approval problem for the EU feed and livestock industries. The reduced import of US maize by-products has been replaced by the use of other feed materials, at a cost to feed compounders and livestock farmers, especially in the ruminant sector. Maize by-products, such as CGF and DDGS is today imported into the EU in small quantities, only around 0.2 million tons a year of each of these two commodities. In 2011, US exports to the EU fell drastically because of a genetically modified corn event, which was not approved for import into the EU. This event was approved for import into the EU in 2012, however, because of the poor US corn harvest, there is a very high demand for feed on the US market and exports to the EU have become scares. A significant improvement in imports cannot be expected until the new US corn harvest in 2013 should increase the supply [9].

In fact, the EU was not able to import maize from the United States from 1997 to 2012 because there has not been a harmonisation of approvals in the EU and the United States. Other countries, primarily Argentina, have provided a substitute for the previous exports from the US. However, in 2007 there were also substantial problems with the importation of maize from Argentina for 
the starch industry as well as for the feed sector due to a GMO trait (event GA21 or "Herculex") not approved in the EU. Until this trait was approved in 2008 maize could only have been exported from Argentina to the EU if the Argentinean authorities had issued an analysis certificate for each shipment confirming the absence of GA21. This time demand for maize in the EU was concentrated on maize from Brazil, which has intensified the acceleration in prices on the feedstuff market. The compound feed producers in the EU had to pay up to $€ 50 / \mathrm{t}$ more for maize from Brazil.

Besides grain, oilmeals also play an important role for the feedstuff supply in the EU. In total, 56 to 58 million tons of protein-rich feedstuffs are used in the EU in year. To a large extent, the oilmeals are imported from third countries ( 36 million tons a year). Soybean meal imports account for 22 - 23 million tons a year. In addition, 10 million tons of soybean meal is produced in the EU, for which 13 million tons of soybeans is imported. Sunseed meal imports amount to 3 million tons a year [9]. EU-27 imports about one third of the soybean meal available in world market. Though China is a biggest consumer of soybean meal it does not directly import meal but beans for crushing ( $60 \%$ of the global trade). EU-27 is the major destination for Argentinian and Brazilian soybean meal. The EU imports soybeans and soybean meal from the three large soybean producing countries.

The adoption rate of GM soybean reached 90\% - 99\% in the USA, Brazil and Argentina that dominate the global cultivation and exports of soybean and soybean meal accounting for $80 \%$ to $90 \%$ of global production and exports. No real alternatives exist to imports from the three large producing and exporting countries since South East Asian countries are major markets of Indian soybean meal. Between 2001 and 2011, global soybean production rose by roughly 88 million tons to 264 million tons or approximately $50 \%$. Of the total soybean production of 264 million tons 220 million tons were crushed and 174 million tons of soybean meal produced. Use of soybean meal in the same marketing year amounted to 170 million tons, of which almost $99 \%$ was used for feeding. China has the largest share of global soybean meal usage, responsible for $25 \%$ of entire global demand. North American farmers are the second largest customers, with $20 \%$ of global usage. In third place comes the EU27 with a share of $18 \%$, followed by South America with a share of $11 \%$. This rise in demand was concentrated in just a few regions (China and other Asian countries). In the EU-27 soybean meal demand has remained stable at 31-33 million tons a year in spite of the EU-enlargement. The EU share in global soybean meal usage has therefore decreased from $26 \%$ in 2000 to $18 \%$ in 2012 [9,10].

The import of soybean and soybean meal for EU live- stock production has become the subject of an intensive political discussion. Proposals are currently being made to replace soybean and soybean meal imports with domestic pulses production, for example on the ecological focus areas that are part of the reform package of the Common Agricultural Policy (CAP) for 2014-2020. In the EU about 245 million tons $(\mathrm{t})$ of feedstocks is used a year, namely 166 million $t$ grain, 31 million $t$ soybean meal, 13 million $\mathrm{t}$ rapeseed meal, 5 million $\mathrm{t}$ sunflower seed meal and 3 million $t$ other oilseed meals. In addition about 7 million $\mathrm{t}$ CGF and DDGS, 11 million $\mathrm{t}$ sugar beet pulp and 8 million $t$ wheat bran is also used. Only 2 million $\mathrm{t}$ peas as well as 2 million $\mathrm{t}$ beans are used as feedstocks [10]. Therefore, the share of soybean meal in the total feed use is around $13 \%$.

The importance of soybean meal for the livestock production sector becomes clear when a protein use statistics is calculated (free amino acids as feed additives are not accounted for here). A total of 43.6 million $t$ of proteins is used in livestock feed in form of the aforementioned feedstock. This value has remained stable since the year 2000. The most important protein source in the EU is grain, representing a share of $40 \%$. In second place however is soybean meal with a share of $34 \%$. Rapeseed meal contributes $11 \%$ to the protein supply, sunflower seed meal $4 \%$ and other oilseeds $2 \%$. Soybean meal is even more important for the supply of essential amino acids, i.e. those amino acids which pigs and poultry can't generate themselves and which often represent the limited factor in feed rations. Based on standard values for the lysine content of different feedstuffs, an EU-wide lysine demand of 2 million $t$ can be calculated in a year. This value has also remained very stable over the last 10 years (does not include the usage of biochemically manufactured lysine). Soybean meal is highly valuable in terms of lysine supply, contributing $46 \%$ of the overall lysine supply. Therefore, soybean meal has a share in EU farmers' feed ratios of approximately $13 \%$, but contributes $34 \%$ to proteins and supplies $46 \%$ of the lysine [11].

The question arises as to how pulses, for example peas with an average protein content of $22.1 \%$, can replace soybean, which contain $36 \%$ of protein. For the calculation, average yields from the last 10 years have been taken as a basis. An average soybean yield in Brazil of $2.73 \mathrm{t} / \mathrm{ha}$ gives an average protein yield of $0.98 \mathrm{t} / \mathrm{ha}$ on the basis of $36 \%$ protein contents. The EU-wide yield of peas is around $3.2 \mathrm{t} / \mathrm{ha}$, giving a protein yield of $0.71 \mathrm{t} / \mathrm{ha}$ on average. Based on these figures, an average of $1.38 \mathrm{ha}$ of peas cultivated in the EU would be needed to replace a hectare of soybeans in Brazil. However, peas replace other crops and their protein output too, for example wheat. A protein content of $11.8 \%$ and an EU-average wheat yield of $5.1 \mathrm{t} / \mathrm{ha}$ gives a crude protein yield of 0.6 
$\mathrm{t} / \mathrm{ha}$ for wheat. An average rapeseed yield of $3 \mathrm{t} / \mathrm{ha}$ and a protein content of $21.6 \%$ in the seed gives a protein yield of $0.65 \mathrm{t} / \mathrm{ha}$. This is all only slightly below the protein yield of pulses. The net yield when substituting wheat or rapeseed with peas works out at just $0.05 \mathrm{t} / \mathrm{ha}$ [11].

A reduction of the wheat acreage in favor of pulses would reduce the EU's export potential, meaning other production regions around the world would have to fill this gap in production. Thus the $5.1 \mathrm{t} / \mathrm{ha}$ per hectare of wheat in the EU would need replacing with approx. 2 ha of wheat production in other parts of the world, where on average only $2.5 \mathrm{t} / \mathrm{ha}$ is produced. The resulting effect based on this simple calculation is that 1.4 ha of peas would have to be planted in the EU in order to replace a single hectare of soybean. However, peas would supplant wheat acreages by $1.4 \mathrm{ha}$. In order to replace wheat production of 1.4 ha in the EU, twice the 1.4 ha acreage would have to be cultivated elsewhere in the world. This means that wheat acreage of 2.8 ha is required in order to replace a single hectare of soybeans in Brazil.

This example shows that farmers' chosen specialization for the most competitive crops in the corresponding location is crucial for fully using the global production potential. Dispensing with specialization therefore leads to a decrease in the global production potential and to a less efficient usage of the scarce factor agricultural land. Assuming all other parameters as unchanged, the EU would consequently cease to be a net exporter of grain.

Within the framework of the reform of the CAP, the greening is being discussed in particular with the ecological focus areas, $7 \%$ of agricultural areas should be taken out of production. However, the cultivation of legumes on these areas should be allowed. This would have effects on the grain importing countries. In the EU 56 million ha of grain is harvested a year. Based on the assumption that a decrease in land cultivated of $7 \%$ would be split proportionally in every crop, only 52 million ha would be planted after the implementation of the greening proposals. With an average yield of $5.1 \mathrm{t} / \mathrm{ha}$ production would shrink from 286 million tons to 265 million tons. In the current marketing year the EU is exporting 10 million tons of grain, net of imports. Assuming all other parameters as unchanged, the EU would consequently cease to be a net exporter of grain. In doing so it would loose its role as a reliable supplier of grain, in particular to North African countries [11].

The EU protein strategy is complex because despite the fact that soybean meal only has a modest share of $13 \%$ of the feeds used, with a share in the protein supply of $34 \%$ and one of $46 \%$ in the lysine supply, its role here is central. A complete substitution of soybean imports therefore seems impossible. A strategy of import substitution or even of set-aside program within the framework of greening does not therefore only have isolated effects on the EU, but also on the entire global market.

\subsection{The GM Debate in Europe}

The GM technology was embraced in North and South America, India and China but in Europe GM crops have yet to be adopted due to vociferous anti-GM campaigns. Mark Lynas points out that the activities and views of such groups have been more influential than scientific facts in shaping government policy and that this situation is unacceptable [12]. The GM debate in Europe often seems to have lost sight of the bigger picture of the challenges in food security and environmental protection and often compares forms of farming (e.g. conventional, IPM, organic) with GM, which is a tool in plant breeding, not a form of farming. The food crisis is a multifaceted problem and no single technology or approach can solve this by itself. The GM debate is too often conducted in an "either this or that technology" mode, rather than recognizing that food security in a combination of all available best approaches. Farmers will need to have as many safe tools at their disposal as possible, and will need to have the freedom to choose what fits best in their approach. The debate sometimes assumes that the food crisis is mainly an issue of (re)distribution and forgets that all approaches have their strengths and weaknesses and that every approach can be used wisely and unwisely.

Asynchronous approval of new GM crops across international jurisdictions is of growing concern due to its potential impact on global trade. Different countries have different authorization procedures and, even if regulatory dossiers are submitted at the same time, approval is not given simultaneously (in some cases, delays can even amount to years). The uneffectiveness of the approval system for GMOs in the EU leads to the blockage of approvals and long delay times caused by political opposition from member states who object to GMOs. The EU has one of the world's strictest approval procedures for GM products. The inconsistency between legally prescribed timelines and the administrative practice has been published by EuropaBio (Figure 2).

The supply chain of commodity crops (e.g. soya and maize) is complex. The EU livestock sector uses imported maize and maize by-products, soybean and soybean meal as animal feed. Countries exporting these crops are growing both EU-authorized and non-EU-authorized GM crops, as well as non-GM crops. The EU decision-making regime for GM products is relatively slow in comparison with the rest of the world (asynchronous GM approvals). The supply of non-GM commodity crops is decreasing as a consequence of an increase in the volume of GM crops being grown and the potential for non-EU authorized GM varieties to enter the non-GM 




Figure 2. GM product submissions and authorizations, status of 1 February 2012 [13].

supply chain as adventitious presence is becoming greater. The adventitious presence thresholds in the EU are the strictest in the world. There is a two-tier tolerance policy with a $0.9 \%$ adventitious presence limit applied to approved products and $0.1 \%$ tolerance applied to unapproved products. The risk that supplies of corn by-products and soya products could be affected by the low-level presence of non-EU approved GM material has not been fully resolved as the EU has allowed just a $0.1 \%$ tolerance for this plus $0.05 \%$ tolerance for measuring uncertainty.

In the EU it is increasingly difficult for poultry and egg suppliers to guarantee that the feed they use is entirely GM free, for two reasons. First, soya is the best source of protein to feed livestock. As soya producers are increasingly turning to GM soya, it means they are producing less non-GM soya, so there simply isn't enough non-GM feed available. It is a global supply issueabout $80 \%$ of the world's soya is now modified. This has had a significant impact on the availability of sufficient quantities of guaranteed non-GM soy at a reasonable cost. Second, because of the way modified crops are planted, processed and transported, it is possible that non-GM soya crops contain low levels of GM soya. The risk of finding GM material in non-GM feed is increasing. In April 2013 four major UK food supermarket groupsTesco, Cooperative, Marks \& Spencer and Sainsbury'shave abandoned their policies that poultry and egg suppliers use only non-GM feed [14].

The world's largest producer of GM-free soy is still Brazil. In 2012, 38 million tons of soybean meal certified as GM-free (NON-GMO-Standard)-i.e. with guaranteed traceability with respect to origin and purity-was produced globally and of this only 7.6 million tons was exported [15]. The discrepancy between the quantities of soybean cultivated as GM-free and the quantities of GMfree certified soya is a result of the fact that products that have undergone the certification process are more costly and only if traders are certain that they can pass on the price surcharge to their customers will they subject their harvest to such a process. If there is no specific demand for GM-free soya, then it may simply be mixed with GM soy and sold as genetically modified. How much GMfree soy is actually delivered to the EU depends on local needs, i.e. on European producers of animal feed and food, on food retailers and on demand from farmers and consumers.

\section{Conclusions}

The EU is dependent for $65 \%$ on imports of protein-rich feedstuffs for which there are no substitutes in the short term. GM and non-GM-soya as a source of protein is imported from the USA, Argentina and Brazil. Demands from the EU differ to those from third countries with respect to the GM varieties grown, and what are authorised for import into the EU. This could potentially cause problems where low level adventitious presence of non-EU authorised GM varieties in imports of GM and non-GM feed would result in the entire consignment being illegal under the EC regulatory framework. This presence is likely to arise from material which is being grown as part of field trials. This could cause supply problems for the animal feed industry, and ultimately supply of food to consumers.

While the absence of CGF and DDGS could be absorbed by rapeseed meal, palm kernel meal and grain (at a higher price, however), soybean meal can only to a very small extent be substituted by other protein feedstuffs. The availability of other protein sources on the world market is nowhere near enough to substitute to an appreciable extent for soybean meal. This is true for the animal protein feedstuffs, fishmeal and meat and bone meal, as well as for the alternative plant protein feedstuffs, such as feed peas, field beans, lupins and also rapeseed meal. Also from a nutritional perspective, soybean meal can be substituted only to a small extent because of the optimal composition of essential amino acids. Moreover, it cannot be expected that other countries will be able to provide the substitute for the exports from the South American countries. First of all, the necessary 
climatic conditions for soybeans limit the number of countries where soybeans can be cultivated. Secondly, it can be assumed that because of the increasing competition between grain and oilseeds (especially soybeans) for area worldwide, soybean acreage will grow only relatively moderately. Increasing competition between farmers in countries like between Brazil and Argentina results in a speeding-up of approvals timelines and the pipeline of GM products is growing.

Global market realities are forcing change in Europe. As countries aim to increase agricultural output, compete for more costly raw materials, or struggle with the impacts of climate change, there will be a further acceleration of GM planting around the world. They will attract agriculture $R \& D$ investment away from Europe and pay less heed to EU views because they have learned that the EU approves the GM products it needs. EU member states dependent on imports will be forced to deal with more GM presence in their chain. Food companies and supermarkets will struggle to stay GM-free. Market forces are forcing governments to authorize products more efficiently, develop tolerance policies or tolerate unapproved varieties in their imports. Consumers will continue to demand more transparency about food content. Most consumers will accept that there is GM content in their food; some will prefer non-GM.

\section{REFERENCES}

[1] J. Popp, K. Pető and J. Nagy, "Pesticide Productivity and Food Security. A Review," Agronomy for Sustainable Development, Vol. 33, No. 1, 2013, pp. 243-255. doi:10.1007/s13593-012-0105-X

[2] E. C. Oerke, "Crop Losses to Pests", Journal of Agricultural Science, Vol. 144, No. 1, 2006, pp. 31-43. doi:10.1017/S0021859605005708

[3] J. Gustavsson, C. Cederberg, U. Sonesson, R. van Otterdijk and A. Meybeck, "Global Food Losses and Food Wastes-Extent, Causes and Prevention," FAO, Rome, 2011.

http://www.fao.org/fileadmin/user_upload/ags/publicatio ns/GFL_web.pdf

[4] J. Popp, "Cost-Benefit Analysis of Crop Protection Meas- ures," Journal of Consumer Protection and Food Safety, Vol. 6, No. S1, 2011, pp. 105-112.

[5] EC, "Economic Impact of Unapproved GMOs on EU Feed Imports and Livestock Production," DG AGRI Report, European Commission, Brussels, 2007.

[6] EC, "Study on the Implications of Asynchronous GMO Approvals for EU Imports of Animal Feed Products," European Commission, Brussels, 2010.

[7] Agra CEAS Consulting, "Assessment of the Scope for the Development of Vegetable Protein Production in the EU," Working Paper, European Union/European Parliament. Bureau Européen de Recherches (Agra CEAS Consulting), Brussels, 2003.

[8] C. James, "2012 ISAAA Report on Global Status of Biotech/GM Crops," International Service for the Acquisition of Agri-Biotech Applications (ISAAA), 2013. http://www.isaaa.org

[9] Toepfer International, "The EU Feed Market in February," Market Review February 2013, Alfred C. Toepfer International GmbH, Hamburg, 2013.

[10] USDA, "Production, Supply and Distribution," United States Department of Agriculture, Foreign Agricultural Service, 2013.

http://www.fas.usda.gov/psdonline/psdQuery.aspx

[11] Toepfer International, "Market Review April 2012," Alfred C. Toepfer International GmbH, Hamburg, 2012.

[12] M. Lynas, "Speech Hosted by the International Programs - College of Agriculture and Life Sciences (50th Anniversary Celebration), and the Atkinson Center for a Sustainable Future," Cornell University, 2013. http://www.marklynas.org/2013/04/time-to-call-out-the-a nti-gmo-conspiracy-theory/

[13] EuropaBio, "Undue Delays in the EU Approval of Safe GM Products," The European Association for Bioindustries, 2012

www.europabio.org/agricultural/positions/approvals-gmo s-european-union

[14] Tesco Food News, “An Update on Poultry Feed,” 2013. http://tescofoodnews.com/news/an-update-on-our-poultry -feed/

[15] Oil Word, “OIL WORLD Database," ISTA Mielke GmbH, Hamburg, 2013.

http://www.oilworld.biz/app.php?ista=1ed1a870cf761b6e $74 \mathrm{e} 4 \mathrm{f0} 07567253330$ 